\title{
The Impact of Human Resources Development Mechanisms on Building Teamwork
}

\author{
Nadera Hourani \\ Faculty of Human Resource Management, King Abdulaziz University \\ Jeddah, Saudi Arabia
}

\section{Keywords}

Human Resources Development, Mechanisms, Learning, Performance Appraisal, Performance Rewards, Teamwork

\begin{abstract}
Purpose of the Paper: This study aimed to explore the impact of human resources development mechanisms on building teamwork.

Design/Methodology: The study has used the descriptive analytical approach, where a questionnaire was employed as the study instrument. The questionnaire consisted of (3) demographic variables and (25) items that were put together to measure the impact of human resources development mechanisms on building teamwork. The study population consisted of all male and female employees that work at five-star hotel chains in the Jordanian capital Amman, which amounts to (15) hotels up until the end of 2017, while the sample of the study consisted of (339) male and female employees, which was chosen using the stratified proportional random sample. (355) questionnaires were distributed; only (346) of them were retrieved, where the loss amounted to (9), and (7) questionnaires were excluded due to their invalidity for analysis.

Findings: The results showed that there is an impact of human resources development mechanisms and its variables (learning, performance appraisal, performance rewards) on building teamwork at $(a \leq 0.05)$.

Practical Implications and Originality Statement: This study will be beneficial for the hotel chains in Amman in general, and for five-star hotel chains in the Jordanian capital Amman and its affiliations in specific. This study can motivate the hotel chains in Jordan to design an accurate strategy that might help them increase the teamwork among their employees.

The researcher certifies that the intellectual content of this paper is the product of her own work and that it has not been submitted elsewhere. The researcher also certifies that all the assistance received in preparing it as well as sources have been acknowledged.
\end{abstract}

Corresponding author: Nadera Hourani

Email addresses for the corresponding author:fgunawan@binus.edu

First submission received: $16^{\text {th }}$ April 2018

Revised submission received: $24^{\text {th }}$ July 2018

Accepted: $30^{\text {th }}$ August 2018

\section{Introduction}

Human resources are considered one of the most important factors of production and assets of an organisation; it is needed in order to develop the competences of the staff, and is involved with all the managerial decisions and practices that have a direct effect on the human resources of an organisation (Solkhe and Chaudhary, 2011).

Human resource development in a business is the sub-system of the human resource management; it is concerned with providing a supportive atmosphere that allows employees to improve their skills for the sake of the company's benefit on one hand, and for themselves on the other. In other words, human resource development mechanisms can be referred to as the various tools used to develop the personnel of the employees of a company (Saraswathi, 2010).

Human resource development can also be referred to as a constant process that aims to ensure the development of employees' abilities, vitality, motivation, and efficiency. In an organisational context, it is referred to as the improvement of the workforces' capabilities in regard to the needs of the organisation. It

www.jbrmr.com A Journal of the Academy of Business and Retail Management (ABRM) 
involves employing the processes through which employees are prepared to give out their best to achieve the objectives of the organisation (Jain, 2014).

The core of any business, regardless of sector, relies on the organisation's greatest asset, its human resources; this is because it determines the success or failure of an organisation. Yet, the value of human resources was not always apparent. In fact, human resource development has been frequently limited to either recruitment, compensation, or legalities to manage the personnel (Richman, 2015).

When employees become aware of the use of performance management data in order to make critical decisions concerning rewards, career management, and skill development, they realise how much the organisation values them and their hard work and therefore, start contributing more (Biron et al., 2011). In addition, formalised job-based performance evaluation guides individuals to achieve higher levels of performance while providing opportunities for two-way communication, thus enhancing the employees' motivation (Wickramasinghe and Liyanage, 2013).

On the other hand, Individuals are mostly interested in performance management that addresses interpersonal and internalised goals, task-performance, a positive work climate, increasing one's standing and position in the organisation, as well as the maintenance of values, in addition to the accomplishment of the task goals that will be influenced by the level of achievements within interpersonal goals, such as maintaining a positive work group climate (Wickramasinghe and Dolamulla, 2017).

Numerous organisations began resorting to human resource mechanisms as strategic tools to promote favourable behaviour among their employees and influence their knowledge and skills, thus, increasing their productivity and performance. For this particular reason, human resource development mechanisms have been recognised as the most foundational activity of the Human Resources system (Rusuli et al., 2017).

However, as demands increased, so did the need to employ human resource development mechanisms; in addition, the modern business environment is facing challenges as well, given the lack of teamwork among its employees. Since the human resources are the most important and valuable resource for any organisation regardless of type. It is competent and motivated employees who achieve the tasks and provide the service in a company, and the more these employees are effective, the more they contribute to the organisation and its customer base. It is also important to build and improve a culture of teamwork in order to develop the business. Thus, contributing to the vitality, capability, motivation, competence, and efficiency of employees is necessary on a continuous basis, as well as providing an environment where teamwork is the foundation for every action that is taken within the organisation. Therefore, the current study was conducted to explore the impact of human resource development mechanisms on building teamwork.

\section{Literature review}

\section{Human resources development mechanisms}

One of the main goals of Human Resources Development is to increase the performance of organisations and make it better. It has been emphasised how important it is to gain competitive advantage through employees and the importance of several Human Resource (HR) practices and their necessity to obtain this advantage, and using an integrated and clear 'bundle' that mutually reinforces Human Resource practices rather than using separate ones (Vermeeren et al., 2014).

According to Uddin et al. (2016), human resource development is essentially defined as a consistency of 3-Cs: competencies, commitment, and culture; these three elements are necessary for organisation to function well; without competencies, an organisation couldn't function efficiency, and without commitment, it would face a slow-paced growth, while culture supports the organisation and allows it to live longer.

Human resource development focuses on improving the current abilities of the employees and helps them gain new competences that are required to achieve both individual as well as organisational objectives. It is considered as an organisational framework that aims to improve and develop the personnel by implementing certain sub-systems or approaches (Rohit, 2017). It has many variables, but for the aims of the current study, only three will be discussed as follows: 


\section{Learning}

Organisational learning is a complicated and a multidimensional concept with different definitions, which cover wide ideas that aim to describe the phenomenon of it. The term is defined as a learning process that requires communication between employees on organisational and inter-organisational levels and involves investigation and analysis in order to achieve the organisation's goals and objectives (Popova-Nowak and Cseh, 2015).

\section{Performance appraisal}

Performance appraisal has become an essential part of the human resource development program within an organisation. It provides knowledge regarding work-related behaviours among individuals as well as a chance to comprehend their strengths and weaknesses and come up with approaches to use their potential by enhancing their weaknesses and improving their strengths. It is useful to both the organisations and its staff, as it provides an assessment of their performance based on their managers' feedback and improve their abilities (Jain, 2014).

\section{Performance rewards}

Rewarding employees for their performance and behaviour is considered important for an organisation, as rewards and recognition advances human resource development, gives employees a sense of accomplishment when rewarded, and increases their loyalty to the organisation. Rewards can also enhance the employee's welfare, which would improve their motivation and ability to perform workrelated targets, making them more profitable and capable of accomplishing tasks (Ebimobowei et al., 2012).

\section{Building teamwork}

Teamwork is one of the most important perceptions that have gotten a lot of consideration. It is defined as an organised group of employees who work together and support each other to achieve a certain objective. Thus, teamwork can be considered a mutual understanding and a collaborative action that intends to achieve the set goals. Teamwork is extremely beneficial to organisations, as it enhances the growth, development, and productivity of its employees (Hanaysha and Tahir, 2016).

Team Building is a process that allows groups to reach their goals and objectives. It consists of various steps, such as clarification of group objectives; distinguish of restraints, and confrontations of recognised challenges and empowering achievement of goals and objectives. It's a combination of assets and information sources working in harmony to accomplish the organisational goals and objectives, where roles are set for each group member, challenges are equally confronted, and incremental developments are pursued persistently (Fapohunda, 2013).

Building effective teams that utilise teamwork efficiently isn't limited to a particular organisation; it is an approach that can be utilised whenever cooperation is required among a group of individuals. It requires them to have the ability to cooperate in order to complete a shared objective efficiently, as well as having the will to contribute to the achievement of their organisation and team. There are two key element that affect building teamwork within organisations, which are team membership and team development, which are both important to building effective project teams and teamwork (Matthews and McLees, 2015).

Given the previously mentioned literature, and being influenced by the results and recommendations of a number of studies, including the study of Wickramasinghe and Dolamulla's (2017), which tested whether or not human resources development mechanisms has an impact on building teamwork, the study of Vermeeren et al. (2014), who believed that performance appraisal has an impact on building teamwork, in addition to the study of Widmann et al. (2016), who assumed that learning and building teamwork are interrelated, and the study of Tohidi (2011), who addressed the impact of rewards on teamwork, the researcher took the previously mentioned studies into account and came with the following main hypothesis and its three sub hypotheses: 
Main Hypothesis $\left(\mathrm{H}_{01}\right)$. There is no impact of human resources development mechanisms and its variables (learning, performance appraisal, performance rewards) on building teamwork at ( $\alpha \leq 0.05)$.

This hypothesis is divided into three sub-hypotheses:

$\mathbf{H}_{01-1}$. There is no impact of learning on building teamwork at $(\alpha \leq 0.05)$.

$\mathbf{H}_{01-2}$. There is no impact of performance appraisal on building teamwork at ( $\left.\alpha \leq 0.05\right)$.

$\mathbf{H}_{01-3}$. There is no impact of performance rewards on building teamwork at $(\alpha \leq 0.05)$.

\section{Methodology}

This study sought to explore the impact of human resources development mechanisms on building teamwork.

The resources of the primary data were collected using a questionnaire instrument.

The research instruments

The instrument contains (25) items that measure the impact of human resources development mechanisms on building teamwork. The questionnaire has been distributed by hand. variables:

The questionnaire contains (3) demographic variables and (25) questions that represent study

Human Resources Development Mechanisms: This variable has been formulated into axis or objectives to reach and has been divided into (3) fields with a total of (15) questions:

Learning, which consists of (5) questions.

Performance Appraisal, which consists of (5) questions.

Performance Rewards, which consists of (5) questions.

Building Teamwork: This variable has been formulated into axis or objectives to reach with a total of (10) questions.

\section{Data analysis and interpretation}

To examine the hypotheses, which were formulated to examine impact of human resources development mechanisms on building teamwork, the Statistical Package for Social Sciences (SPSS) has been used to processing the following statistical techniques and tests in data analysis:

Descriptive Statistical Techniques: These included means and standard deviations. These techniques were used to illustrate responses to the study fields;

Reliability Test, which was used to measure the reliability of the instruments and highlight its stability of consistency;

Frequencies and Percentages, which were used to describe demographical variables;

Normality Tests;

Linear Regression Test, which was used to explore the direct impacts of variables.

Respondents were asked to read each item, and select one of the choices as follows:

Score 5 for (strongly agree)

Score 4 for (agree)

Score 3 for (neutral)

Score 2 for (disagree)

Score 1 for (strongly disagree)

Population and sample

Sample of the study

The study population consisted of all five-star hotel chains in the Jordanian capital Amman, which amounts to (15) hotels up until the end of 2017, according to the Jordan Hotel Association (2017). A stratified proportional random sample was chosen from the population, where it was partitioned into groups called "strata," and from each strata, a random sample, was drawn independently. (355) questionnaires were distributed, and (346) were retrieved, while (7) questionnaires were excluded due to their lack of validity for the analysis, making the number of valid questionnaires valid for the analysis 
(339), which were identified as (95.5\%) of the total of distributed questionnaires, as it is classified into its demographic characteristics in the table below:

\begin{tabular}{|l|l|l|l|}
\hline \multirow{2}{*}{ Demographic Characteristics } & \multirow{2}{*}{ Rank } & \multicolumn{2}{|c|}{ Sample } \\
\cline { 2 - 4 } & & Frequency & Percentage \\
\hline \multirow{3}{*}{ Gender } & Male & 201 & $59.3 \%$ \\
\cline { 2 - 4 } & Female & 138 & $40.7 \%$ \\
\cline { 2 - 4 } & Total & $\mathbf{3 3 9}$ & $\mathbf{1 0 0 . 0} \%$ \\
\hline \multirow{4}{*}{ Academic Level } & High School Degree or Below & 65 & $19.2 \%$ \\
\cline { 2 - 4 } & Bachelor's Degree & 239 & $70.5 \%$ \\
\cline { 2 - 4 } & Master's Degree & 25 & $7.4 \%$ \\
\cline { 2 - 4 } & Doctorate Degree & 10 & $2.9 \%$ \\
\cline { 2 - 4 } & Total & $\mathbf{3 3 9}$ & $\mathbf{1 0 0 . 0} \%$ \\
\hline \multirow{4}{*}{ Years of Experience } & Less than 1 year & 127 & $37.5 \%$ \\
\cline { 2 - 4 } & $\mathbf{1 - 3 y e a r s}$ & 137 & $40.4 \%$ \\
\cline { 2 - 4 } & $\mathbf{3 - 5}$ Years & 36 & $10.6 \%$ \\
\cline { 2 - 4 } & More than 5 years & 39 & $11.5 \%$ \\
\cline { 2 - 4 } & Total & $\mathbf{3 3 9}$ & $\mathbf{1 0 0 . 0} \%$ \\
\hline
\end{tabular}

Table (1): Demographic Characteristics for the Study Sample in Accordance with (Gender, Academic Level, Years of Experience)

Table (1) shows the demographic characteristics for the study sample in accordance with gender, academic level, and years of experience. As seen above, the percentage of males was (59.3\%) from the total sample, while the percentage of females was (40.7\%). As for the variable of (Academic Level), it seemed that the (High School Degree or below) rank achieved (19.2\%), and the (Bachelor's Degree) rank achieved (70.5\%), while the (Master's Degree) rank achieved (7.4\%) and the (Doctorate Degree) rank achieved (2.9\%). The variable (Years of Experience), it seemed that the (Less than 1 year) rank achieved (37.0\%), and the (1-3 years) rank achieved (40.4\%), while the (3-5 years) rank achieved $(10.6 \%)$ and the (More than 5 years) rank achieved (11.5\%).

Tool validity

\begin{tabular}{|c|c|c|}
\hline $\begin{array}{l}\text { Field } \\
\text { Number }\end{array}$ & Field & Value of $(\alpha)$ \\
\hline \multicolumn{3}{|c|}{ Human Resources Development Mechanisms } \\
\hline 1 & Learning & 0.787 \\
\hline 2 & Performance Appraisal & 0.737 \\
\hline 3 & Performance Rewards & 0.846 \\
\hline \multicolumn{3}{|c|}{ Building Teamwork } \\
\hline 1 & Building Teamwork & 0.634 \\
\hline
\end{tabular}

Table (2): Cronbach's Alpha for the Study Fields

As shown from the table above, the total Cronbach's Alpha for the study fields was above than $(0.60)$, which will lead to the stability of the results for this study.

\section{Analysis of the results}

To analyse the data, examine the hypotheses, and explore the relationship between human resources development mechanisms and building teamwork, descriptive statistics for each field has been calculated, in addition to using linear regression, as shown below.

\section{Descriptive statistics for the instrument's fields}

Means and standard deviations were calculated for each field of the study instrument. Results are shown in table (3) below. 


\begin{tabular}{|l|l|l|l|l|}
\hline $\begin{array}{l}\text { Field } \\
\text { Number }\end{array}$ & Field & Mean & Std. Deviation & Level \\
\hline F1 & Learning & 4.35 & 0.29 & High \\
\hline F2 & Performance Appraisal & 4.09 & 0.31 & High \\
\hline F3 & Performance Rewards & 3.90 & 0.52 & High \\
\hline F4 & Building Teamwork & 4.05 & 0.29 & High \\
\hline
\end{tabular}

Table (3): Descriptive Statistics for Identity Human Resources Development and Building

Teamwork

As seen from the above table, the (Learning) field achieved a mean of (4.35) and a standard deviation of (0.29), while the (Performance Appraisal) field achieved a mean of (4.09) and a standard deviation of (0.31), and the (Performance Rewards) achieved a mean of (3.90), and a standard deviation of (0.52). It has also shown that the (Building Teamwork) field achieved a mean of (4.05), and a standard deviation of (0.29).

\section{Descriptive statistics for the learning field}

Means and standard deviations were calculated for each item in the (Learning) field. Results are shown in table (4) below.

\begin{tabular}{|c|l|l|l|l|}
\hline $\begin{array}{c}\text { Question } \\
\text { Number }\end{array}$ & \multicolumn{1}{|c|}{ Question } & Mean & Std. Deviation & Rank \\
\hline 4 & $\begin{array}{l}\text { The hotel management provides employees with job aids, } \\
\text { such as resources or technology, to support what employees } \\
\text { learned during training programmes. }\end{array}$ & 4.55 & 0.54 & 1 \\
\hline 3 & $\begin{array}{l}\text { The hotel management keeps its staff motivated to learn the } \\
\text { concepts that will be covered in the training programmes. }\end{array}$ & 4.44 & 0.55 & 2 \\
\hline 1 & $\begin{array}{l}\text { Employees are willing to exert effort to improve their } \\
\text { knowledge by participating in training programmes. }\end{array}$ & 4.36 & 0.53 & 3 \\
\hline 5 & $\begin{array}{l}\text { The hotel management provides employees with the } \\
\text { opportunity to acquire technical knowledge and skills } \\
\text { through training programmes. }\end{array}$ & 4.24 & 0.51 & 4 \\
\hline 2 & $\begin{array}{l}\text { The hotel management conducts periodic training } \\
\text { programmes for its employees to expand their knowledge } \\
\text { and skills. }\end{array}$ & 4.18 & 0.5 & 5 \\
\hline & \multicolumn{1}{|c|}{ Total } & 4.35 & 0.29 & \\
\hline
\end{tabular}

Table (4): Descriptive Statistics for Learning Field

As seen from the above table, the total mean for this field was (4.35) with a standard deviation of (0.29). It is also noted that question (4), which states, "The hotel management provides employees with job aids, such as resources or technology, to support what employees learned during training programmes," ranked first with a mean of (4.55) and a standard deviation of (0.54), while question (2), which states, "the hotel management conducts periodic training programmes for its employees to expand their knowledge and skills," came in the final rank with a mean of (4.18) and a standard deviation of (0.50).

\section{Descriptive statistics for the performance appraisal field}

Means and standard deviations were calculated for each item in the (Performance Appraisal) field. Results are shown in table (5) below. 


\begin{tabular}{|l|l|l|l|l|}
\hline $\begin{array}{l}\text { Question } \\
\text { Number }\end{array}$ & \multicolumn{1}{|c|}{ Question } & Mean & Std. Deviation & Rank \\
\hline 9 & $\begin{array}{l}\text { The appraisal system provides employees with the } \\
\text { opportunity to express their developmental needs. }\end{array}$ & 4.23 & 0.51 & 1 \\
\hline 8 & $\begin{array}{l}\text { The appraisal system provides employees with the } \\
\text { opportunity to discuss expectations, achievements, failures, } \\
\text { constraints, and improvements required. }\end{array}$ & 4.18 & 0.51 & 2 \\
\hline 10 & $\begin{array}{l}\text { The hotel management spends time discussing performance } \\
\text { with its employees. }\end{array}$ & 4.15 & 0.55 & 3 \\
\hline 6 & $\begin{array}{l}\text { The appraisal data is used to recognise and encourage high- } \\
\text { performing employees as well as desirable behaviours. }\end{array}$ & 3.99 & 0.51 & 4 \\
\hline 7 & $\begin{array}{l}\text { The appraisal system helps employees gain more insights } \\
\text { regarding their strengths and weaknesses. }\end{array}$ & 3.87 & 0.60 & 5 \\
\hline & Total & 4.09 & 0.31 & \\
\hline
\end{tabular}

Table (5): Descriptive Statistics for Performance Appraisal Field

As seen from the above table, the total mean for this field was (4.09) with a standard deviation of (0.31). It is also noted that question (9), which states, "The appraisal system provides employees with the opportunity to express their developmental needs," ranked first with a mean of (4.23) and a standard deviation of (0.51), while question (7), which states, "The appraisal system helps employees gain more insights regarding their strengths and weaknesses," came in the final rank with a mean of (3.87) and a standard deviation of $(0.60)$.

Descriptive statistics for the performance rewards field

Means and standard deviations were calculated for each item in the (Performance Appraisal) field. Results are shown in table (6) below.

\begin{tabular}{|c|c|c|c|c|}
\hline $\begin{array}{l}\text { Question } \\
\text { Number }\end{array}$ & Question & Mean & Std. Deviation & Rank \\
\hline 11 & $\begin{array}{l}\text { The hotel management explicitly recognises and rewards } \\
\text { employees who are a source of quality information. }\end{array}$ & 4.44 & 0.55 & 1 \\
\hline 12 & $\begin{array}{l}\text { The hotel management has a reward system that facilitates } \\
\text { the implementation of strategies by motivating the desired } \\
\text { levels of performance among its employees. }\end{array}$ & 3.84 & 0.64 & 2 \\
\hline 14 & $\begin{array}{l}\text { The hotel management recognises employees who are taking } \\
\text { initiative. }\end{array}$ & 3.81 & 0.64 & 3 \\
\hline 13 & $\begin{array}{l}\text { The hotel management has mechanisms to reward } \\
\text { employees for their performance or noteworthy } \\
\text { contributions. }\end{array}$ & 3.77 & 0.76 & 4 \\
\hline 15 & $\begin{array}{l}\text { The hotel management recognises and rewards employees } \\
\text { who provide direction to improve organisational success at } \\
\text { every level. }\end{array}$ & 3.64 & 0.64 & 5 \\
\hline & Total & 3.90 & 0.52 & \\
\hline
\end{tabular}

Table (6): Descriptive Statistics for Performance Rewards Field

As seen from the above table, the total mean for this field was (3.90) with a standard deviation of (0.52). It is also noted that question (11), which states, "The hotel management explicitly recognises and rewards employees who are a source of quality information," ranked first with a mean of (4.44) and a standard deviation of (0.55), while question (15), which states, "the hotel management recognises and rewards employees who provide direction to improve organisational success at every level," came in the final rank with a mean of (3.64) and a standard deviation of (0.64).

Descriptive statistics for the building teamwork field

Means and standard deviations were calculated for each item in the (Building Teamwork) field. Results are shown in table (7) below. 


\begin{tabular}{|c|c|c|c|c|}
\hline $\begin{array}{l}\text { Question } \\
\text { Number }\end{array}$ & Question & Mean & Std. Deviation & Rank \\
\hline 16 & $\begin{array}{l}\text { Team members are equally well informed about changes } \\
\text { within the hotel. }\end{array}$ & 4.47 & 0.55 & 1 \\
\hline 19 & $\begin{array}{l}\text { The hotel management employs teamwork policies } \\
\text { whenever possible. }\end{array}$ & 4.46 & 0.55 & 2 \\
\hline 20 & $\begin{array}{l}\text { The hotel management ensures that each member has an } \\
\text { active role with the team. }\end{array}$ & 4.33 & 0.54 & 3 \\
\hline 22 & $\begin{array}{l}\text { The hotel management ensures that members of the team } \\
\text { express trust in the other members. }\end{array}$ & 4.22 & 0.47 & 4 \\
\hline 21 & $\begin{array}{l}\text { The hotel management ensures that its employees enjoy } \\
\text { their work in a stress-free atmosphere. }\end{array}$ & 4.18 & 0.59 & 5 \\
\hline 18 & $\begin{array}{l}\text { The hotel management emphasises the importance of } \\
\text { teamwork. }\end{array}$ & 4.16 & 0.49 & 6 \\
\hline 17 & $\begin{array}{l}\text { The hotel management conducts teambuilding exercises that } \\
\text { require cooperation on a regular basis. }\end{array}$ & 4.11 & 0.56 & 7 \\
\hline 23 & $\begin{array}{l}\text { The hotel management provides its employees with the } \\
\text { opportunity to use two-way communication on a regular } \\
\text { basis. }\end{array}$ & 3.78 & 0.64 & 8 \\
\hline 24 & $\begin{array}{l}\text { The hotel management provides its employees with the } \\
\text { opportunity to express their opinions and give suggestions. }\end{array}$ & 3.49 & 0.54 & 9 \\
\hline 25 & $\begin{array}{l}\text { The hotel management provides its employees with the } \\
\text { opportunity to engage with and assist their supervisors in } \\
\text { making decisions. }\end{array}$ & 3.32 & 0.60 & 10 \\
\hline & Total & 4.05 & 0.29 & \\
\hline
\end{tabular}

\section{Table (7): Descriptive Statistics for Building Teamwork Field}

As seen from the above table, the total mean for this field was (4.05) with a standard deviation of (0.29). It is also noted that question (16), which states, "Team members are equally well informed about changes within the hotel," ranked first with a mean of (4.47) and a standard deviation of (0.55), while question (25), which states, "The hotel management provides its employees with the opportunity to engage with and assist their supervisors in making decisions," came in the final rank with a mean of (3.32) and a standard deviation of (0.60).

\section{Hypotheses}

Main Hypothesis $\left(\mathrm{H}_{01}\right)$. There is no impact of human resources development mechanisms and its variables (learning, performance appraisal, performance rewards) on building teamwork at ( $\alpha \leq 0.05)$.

$\mathrm{H}_{01-1}$. There is no impact of learning on building teamwork at $(\alpha \leq 0.05)$.

To check the validity of linear regression for this model, VIF and Tolerance were calculated for each field for independent variables as shown in the following table:

\begin{tabular}{|l|l|l|}
\hline Field & Tolerance & VIF \\
\hline Learning & .285 & 3.513 \\
\hline Performance Appraisal & .273 & 3.664 \\
\hline Performance Rewards & .470 & 2.128 \\
\hline
\end{tabular}

As shown in the table above, it seems that all VIF values are (Less than 10), which leads to the compatibility of using a regression test. As for Tolerance values, they were more than (0.05), which means that the regression modelling can be used to test the hypothesis.

The simple regression test has been used to check the direct impact of learning on building teamwork, which is shown in the table below: 


\begin{tabular}{|c|c|c|c|c|c|c|c|c|}
\hline \multirow{2}{*}{ Dependent Variable } & & \multirow[b]{2}{*}{2} & \multirow{2}{*}{$\mathbf{F}$} & \multirow[b]{2}{*}{$\mathbf{F}$} & \multicolumn{3}{|c|}{ Coefficients } & \multirow[b]{2}{*}{ Sig } \\
\hline & & & & & Predictor & B & $\mathrm{T}$ & \\
\hline \multirow[t]{2}{*}{ Building Teamwork } & \multirow{2}{*}{623} & \multirow{2}{*}{388} & \multirow[t]{2}{*}{214.023} & 37 & \multirow[t]{2}{*}{ Learning } & \multirow[t]{2}{*}{0.627} & \multirow[t]{2}{*}{14.630} & \multirow[t]{2}{*}{0.000} \\
\hline & & & & 38 & & & & \\
\hline
\end{tabular}

\section{Teamwork}

Table (8): Simple Regression Test to Check the Direct Impact of Learning on Building

As shown in the table above, the results indicated that there is a significant impact of learning on building teamwork, because the significant value was (0.000), which is less than $(0.05)$, and the value of $(\mathrm{r})$ is the square root of r-squared, while the correlation between the observed and predicted values of the dependent variable was (0.623), and the coefficient of determination $\mathrm{r}^{2}$ was $(0.388)$. Therefore, about $(38.8 \%)$ of the variation in building teamwork is explained by learning. The restriction parameter (f) was (214.023) of (building teamwork) that is caused by learning, and thus, the alternative hypotheses "There is an impact learning on building teamwork at $(\alpha \leq 0.05)$ " will be accepted.

$\mathbf{H}_{01-2}$. There is no impact of performance appraisal on building teamwork at $(\alpha \leq 0.05)$.

The simple regression test has been used to check the direct impact of performance appraisal on building teamwork, which is shown in the table below:

\begin{tabular}{|c|c|c|c|c|c|c|c|c|}
\hline \multirow{2}{*}{ Dependent Variable } & \multirow{2}{*}{$\mathrm{R}$} & \multirow{2}{*}{$\mathrm{R}^{2}$} & \multirow{2}{*}{$\mathrm{F}$} & \multirow{2}{*}{$\mathrm{DF}$} & \multicolumn{4}{|l|}{ Coefficients } \\
\hline & & & & & Predictor & B & $\mathrm{T}$ & Sig \\
\hline \multirow{3}{*}{ Building Teamwork } & \multirow{3}{*}{.523} & \multirow{3}{*}{.273} & \multirow{3}{*}{126.605} & 1 & \multirow{3}{*}{ Performance Appraisal } & \multirow{3}{*}{0.492} & \multirow{3}{*}{11.252} & \multirow{3}{*}{0.000} \\
\hline & & & & 37 & & & & \\
\hline & & & & 38 & & & & \\
\hline
\end{tabular}

Table (9): Simple Regression Test to Check the Direct Impact of Performance Appraisal on Building Teamwork

As shown in the table above, the results indicated that there is a significant impact of performance appraisal on building teamwork, because the significant value was $(0.000)$, which is less than (0.05), and the value of $(\mathrm{r})$ is the square root of r-squared, while the correlation between the observed and predicted values of the dependent variable was (0.523), and the coefficient of determination $\mathrm{r}^{2}$ was $(0.273)$. Therefore, about $(27.3 \%)$ of the variation in building teamwork is explained by performance appraisal. The restriction parameter (f) was (126.605) of (building teamwork) that is caused by performance appraisal, and thus, the alternative hypotheses "There is an impact performance appraisal on building teamwork at $(\alpha \leq 0.05)$ " will be accepted.

$\mathrm{H}_{01-3}$. There is no impact of performance rewards on building teamwork at ( $\left.\alpha \leq 0.05\right)$.

The simple regression test has been used to check the direct impact of performance rewards on building teamwork, which is shown in the table below:

\begin{tabular}{|c|c|c|c|c|c|c|c|c|}
\hline \multirow{2}{*}{ Dependent Variable } & \multirow{2}{*}{$\mathrm{R}$} & \multirow{2}{*}{$\mathrm{R}^{2}$} & \multirow{2}{*}{$\mathrm{F}$} & \multirow{2}{*}{$\mathrm{DF}$} & \multicolumn{4}{|l|}{ Coefficients } \\
\hline & & & & & Predictor & B & $\mathrm{T}$ & Sig \\
\hline \multirow{3}{*}{ Building Teamwork } & \multirow{3}{*}{.605} & \multirow{3}{*}{.366} & \multirow{3}{*}{194.247} & 1 & \multirow{3}{*}{ Performance Rewards } & \multirow{3}{*}{0.333} & \multirow{3}{*}{13.937} & \multirow{3}{*}{0.000} \\
\hline & & & & 37 & & & & \\
\hline & & & & 38 & & & & \\
\hline
\end{tabular}

Table (10): Simple Regression Test to Check the Direct Impact of Performance Rewards on Building Teamwork 
As shown in the table above, the results indicated that there is a significant impact of performance rewards on building teamwork, because the significant value was $(0.000)$, which is less than $(0.05)$, and the value of $(r)$ is the square root of r-squared, while the correlation between the observed and predicted values of the dependent variable was (0.605), and the coefficient of determination $\mathrm{r}^{2}$ was (0.366). Therefore, about $(36.6 \%)$ of the variation in building teamwork is explained by performance rewards. The restriction parameter (f) was (194.247) of (building teamwork) that is caused by performance rewards, and thus, the alternative hypotheses "There is an impact performance rewards on building teamwork at ( $\alpha \leq$ 0.05)" will be accepted.

\section{Discussions and conclusions \\ Discussions \\ Discussion of the Results \\ First: Human Resources Development Mechanisms}

The results of the means and standard deviations of the human resources development mechanisms fields from the point of view of the analysis unit showed that they were high, where the Performance Rewards field came first, and the Learning field came last. This indicates that five-star hotel chains in the Jordanian capital Amman care about wellbeing of their employees and staff and make sure that they reward them appropriately so they remain engaged and motivated, which would also retain them in the long run.

This can be supported by Wickramasinghe and Dolamulla's (2017) study, which showed that human resources development mechanisms play a significant role in employees' perceptions of achieving team interpersonal goals.

\section{Learning}

The results showed that the total mean and standard deviations of the Learning field were high. Question (4) ranked first with high importance, while question (2) came in the last place with high importance. This is because five-star hotel chains in the Jordanian capital Amman are keen to provide their employees with a convenient working environment and numerous training programmes that enable them to develop their skills and expertise within their field of work.

This can be supported by Widmann et al. (2016), who showed that that learning, and innovation developments are dependent aspects of teamwork.

\section{Performance Appraisal}

The results showed that the total mean and standard deviations of the Performance Appraisal field were high. Question (9) ranked first with high importance, while question (7) came in the last place with high importance. This is because five-star hotel chains in the Jordanian capital Amman believe in the importance of meeting their employees' needs and encourage them to express those needs in order to meet them and thus, ensure the loyalty among the employees.

This is supported by Vermeeren et al. (2014), who implied that there is a positive relationship between teamwork and performance appraisal, as employers use performance appraisal under circumstances that contribute to trust and cooperation among team members.

In addition,

\section{Performance Rewards}

The results showed that the total mean and standard deviations of the Performance Rewards field were high. Question (11) ranked first with high importance, while question (15) came in the last place with high importance. This is because five-star hotel chains in the Jordanian capital Amman appreciate the efforts put in by their employees and believes in the importance of rewarding them in order to retain their loyalty towards the hotel and the work they are performing.

This is approved by Tohidi (2011), who pointed out that reinforcement of teamwork using reward systems is necessary and effective.

\section{Second: Building Teamwork}

The results showed that the total mean and standard deviations of the Building Teamwork field were high. Question (16) ranked first with high importance, while question (25) came in the last place with 
high importance. This is because five-star hotel chains in the Jordanian capital Amman believe that employees would have a more positive attitude toward their work and customers when they feel like they are part of the company, as it builds trust and encourages engagement and retention, which is approved by Manzoor et al. (2011).

\section{Discussion of the Hypotheses' Results}

The main hypothesis $\left(\mathbf{H}_{01}\right)$ showed an impact of human resources development mechanisms at $(\alpha \leq 0.05)$ on building teamwork. This is because five-star hotel chains in the Jordanian capital Amman care about implementing mechanisms and strategies that would nourish their staff and help them improve and develop in their careers and come up with creative ways to enhance the services and goods provided by their workplace.

This is supported by Kesti (2012), who HR-development actions have a positive impact on working groups and their implementation of optimal workplace innovations, only when they are executed effectively enough.

This hypothesis is divided into three sub-hypotheses:

The first sub-hypothesis $\left(\mathrm{H}_{01-1}\right)$ showed an impact of learning at $(\alpha \leq 0.05)$ on building teamwork. This is due to the keenness of five-star hotel chains in the Jordanian capital Amman to hold training courses that would improve and develop the skills and expertise of their employees as well as providing new experiences that would enhance their creative thinking and encourages them to come up with new knowledge.

This can be supported by Sarawat and Khandelwal (2015) who suggested that learning and reinforcement are necessities for Team building to result in actionable ideas to help the team and the organization achieve their goals.

The second sub-hypothesis $\left(\mathbf{H}_{01-2}\right)$ showed an impact of performance appraisal at $(\alpha \leq 0.05)$ on building teamwork. This is due to the keenness of five-star hotel chains in the Jordanian capital Amman to ensure that each and every employee are performing their duties and provide guidance to them along the way so as to maintain a healthy and productive workplace.

This is reinforced Karabat, B. and Çaliş (2017), who implied that that participants' perception of the performance appraisal systems of their own teams is positive yet around the intermediate level.

The third sub-hypothesis $\left(\mathbf{H}_{01-3}\right)$ showed an impact of performance rewards at $(\alpha \leq 0.05)$ on building teamwork. This is due to the keenness of five-star hotel chains in the Jordanian capital Amman to identify the creative and hardworking employees and reward them, thus keeping them motivated and loyal, while encouraging other employees to follow their colleagues' example.

This has been emphasized by Jiang (2010), who believes that rewards based on performance or contribution has an impact on teamwork, as teams work hard and share responsibility together.

\section{Conclusions}

Human resource development stands out as a sequence of actions that support change and learning opportunities that can be available for employees, which aims to develop their skills and flexibility in order to meet the needs and demands of their organisation, which the main objective of achieving high performance within the company (Richman, 2015).

As a way to highlight the relationship between human resources development mechanisms and building teamwork, it was necessary to perceive how human resources development mechanisms and its variables (learning, performance appraisal, performance rewards) affects building teamwork. Thus, and as seen through the results of this descriptive analytical approach, there is an impact of human resources development mechanisms and its variables (learning, performance appraisal, performance rewards) on building teamwork at $(\alpha \leq 0.05)$, all of which were high.

The importance of human resource development mechanism is beginning to be accepted by the whole world, especially in hotel chains coupled with the widespread crisis in the global economy in general, and the Jordanian economy in specific. Thus, human resource development mechanism has 
become a crucial requirement any business to grow, as it is considered with the development of competency of people, who are the foundation of any thriving business.

The present study was made as an attempt to explore the impact of three of these mechanisms (learning, performance appraisal, and performance rewards) on building teamwork in five-star hotel chains in the Jordanian capital Amman. In light of the results shown in this study, it has been concluded that organisations, especially hotel chains should pay HRD mechanisms more attention in order to thrive as a business; as these mechanisms help the employees expand their knowledge and expertise. In addition, competent people in all areas and fields are needed in order to be have a productive working environment, as dimensions such as cost reduction, delay reduction, customer satisfaction, quality, prompt service, market image, etc. are immensely affected by the employees' knowledge and performance.

Thus, the author suggests that further research should be carried out regarding human resources development mechanisms and building teamwork within different populations other than Jordanian hotels.

\section{Research limitations and direction for further research}

There were some limitations within this study that must be taken into account; first being the human limitation, where the population of the study was limited to include employees at five-star hotel chains in the Jordanian capital Amman only. The second limitation would be insincerity and conflict when answering the questionnaire by some of the employees, resulting in these questionnaires being excluded by the researcher and not being included in the final analysis.

While choosing employees who worked at five-star hotel chains in the Jordanian capital Amman was an effective method, it would've been more effective to include a larger sample to obtain better results. It would also be preferable to include other five-star hotel chains from across the entire Hashemite Kingdom of Jordan. Further qualitative research would be needed in the future to accurately measure the impact of human resources development mechanisms on building teamwork.

Further research into the broader impact of human resources development mechanisms on building teamwork any new outcomes, whether they are positive or negative, would be appreciated by the researchers.

\section{References}

Biron, M., Farndale, E., and Paauwe, J. (2011). Performance Management Effectiveness: Lessons from World-Leading Firms. The International Journal of Human Resource Management, 22(6), pp.1294-1311.

Ebimobowei, A., Felix, T., and Wisdom, S. (2012). Human Resource Development Mechanism and the Performance of Public Sector Accountants. Current Research Journal of Social Sciences, 4(3), pp.246-255.

Fapohunda, T. (2013). Towards Effective Team Building in the Workplace. International Journal of Education and Research, 1(4), pp.1-12.

Hanaysha, J. and Tahir, P. (2016). Examining the Effects of Employee Empowerment, Teamwork, and Employee Training on Job Satisfaction. Procedia-Social and Behavioral Sciences, 219, pp.272-282.

Jain, V. (2014). An Overview of Human Resource Development Programmes in Indian Industries. IOSR Journal of Business and Management, 16(3), pp.21-31.

Jain, V. (2014). Performance Appraisal as a Sub-system of HRD-A Case Study. IOSR Journal of Business and Management, 16(1), pp.26-34.

Jiang, X. (2010). How to Motivate People Working in Teams. International Journal of Business and Management, 5(10), 223-229.

Jirjahn, U. and Poutsma, E. (2013). The Use of Performance Appraisal Systems: Evidence from Dutch Establishment Data. Industrial Relations: A Journal of Economy and Society, 52(4), pp.801-828.

Jordan Hotel Association (2017). JHA Annual Report 2017. Retrieved 04/03/2018 from http://johotels.org/Photos/Files/71418111-8f00-4b30-bafa-8526e45b726e.pdf

Karabat, B. and Çaliş, Ş. (2017). Team Based Performance Appraisal Systems: Scale Development and Validation. The Sakarya Journal of Economics, 6(1), pp.30-55.

Kesti, M. (2012). Organization Human Resources Development Connection to Business Performance. Procedia Economics and Finance, 2, pp.257-264. 
Manzoor, S., HafizUllah, Hussain, M., Ahmad, Z. (2011). Effect of Teamwork on Employee Performance. International Journal of Learning and Development, 1(1), pp.110-126.

Matthews, R. and McLees, J. (2015). Building Effective Projects Teams and Teamwork. Journal of Information Technology and Economic Development, 6(2), pp.20-30.

Popova-Nowak, I. and Cseh, M. (2015). The Meaning of Organizational Learning: A Meta-Paradigm Perspective. Human Resource Development Review, 14(3), pp.299-331.

Richman, N. (2015). Human Resource Management and Human Resource Development: Evolution and Contributions. Creighton Journal of Interdisciplinary Leadership, 1(2), pp.120-129.

Rohit, D. (2017). Human Resource Development: Policies and Practices in Private Sector Banks in Gujarat. Voice of Research, 6(1), pp.44-49.

Rusuli, C., Nazri, M., Mohammad, I., Fauzan, H., Suhaila, A., Azemawati, I., and Hasannuddiin, H. (2017). The Mediating Effect of Employee Competencies on the Relationship between Human Resource Development Practice and Service Performance among Front Line Employees in Hotel Industries. International Journal of Applied Business and Economic Research, 15(22), pp.451-464.

Saraswat, N. and Khandelwal, S. (2015). Impact of Team Building Exercises on Team Effectiveness. International Journal of Marketing and Human Resource Management, 6(3), pp.89-97.

Saraswathi, S. (2010). Human Resources Development Climate: An Empirical Study. International Journal of Innovation, Management and Technology, 1(2), pp.174-179.

Solkhe, A. and Chaudhary, N. (2011). HRD Climate and Job Satisfaction: An Empirical Investigation. International Journal of Computing and Business Research, 2(2), pp.1-20.

Tohidi, H. (2011). Teamwork Productivity and Effectiveness in an Organization Base on Rewards, Leadership, Training, Goals, Wage, Size, Motivation, Measurement and Information Technology. Procedia Computer Science, 3, pp.1137-1146.

Uddin, M., Naher, K., Bulbul, A., Ahmad, N., and Rahman, M. (2016). The Impact of Human Resource Development (HRD) Practices on Organizational Effectiveness: A Review. Asian Business Review, 6(3), pp.131-140.

Vermeeren, B., Steijn, B., Tummers, L., Lankhaar, M., Poerstamper, R., and Van Beek, S. (2014). HRM and Its Effect on Employee, Organizational and Financial Outcomes in Health Care Organizations. Human Resources for Health, 12(1), p.35.

Wickramasinghe, V. and Dolamulla, S. (2017). The Effects of HRM Practices on Teamwork and Career Growth in Offshore Outsourcing Firms. Global Business and Organizational Excellence, 36(2), pp.46-60.

Wickramasinghe, V. and Liyanage, S. (2013). Effects of High-Performance Work Practices on Job Performance in Projectbased Organizations. Project Management Journal, 44(3), pp.64-77.

Widmann, A., Messmann, G., and Mulder, R. (2016). The Impact of Team Learning Behaviors on Team Innovative Work Behavior: A Systematic Review. Human Resource Development Review, 15(4), pp.429-458. 